\title{
CONSTRUCTION OF SIGNS AND MYTHS IN PRE-WEDDING PHOTOGRAPHY
}

\author{
Wahyu Lukito ${ }^{1}$, Intan Rizky Mutiaz², Yasraf Amir Piliang ${ }^{3}$ \\ 1,2,3 Bandung Institute of Technology
}

\begin{abstract}
In pre-wedding photograph there are visual signs those break conventional codes, then create unconventional concepts, which have potentials to create unconventional myth on pre-wedding photograph. The objectives of this research are to identify visual signs, unconventional codes and concepts on pre-wedding photograph. Through the observation toward some pre-wedding photograph samples those taken purposively base on have unconventional codes trend, analyze with photography semiotic toward pre-wedding photograph which uploaded in vendor's Instagram account within a certain period, describe unconventional code those create unconventional concepts which have potential to create unconventional myth on pre-wedding photograph. The unconventional codes created through breaking conventional codes process on them. The breaking process through modifies the visual signs, which not generally applied on pre-wedding photographs. And also the breaking process creates unconventional concepts on pre-wedding photograph, which have potential to create unconventional myth for long time to go.
\end{abstract}

Keywords: Code, Myth, Pre-wedding, Photography, Sign

\begin{abstract}
Abstrak: Dalam fotografi pre-wedding terdapat tanda-tanda visual yang mematahkan kode konvensional, kemudian membentuk konsep inkonvensional, yang memiliki potensi untuk membentuk mitos inkonvensional pada suatu foto pre-wedding. Tujuan dari penelitian ini adalah untuk mengidentifikasi tanda-tanda visual, kode-kode dan konsep inkonvensional dalam foto pre-wedding. Melalui observasi terhadap beberapa sampel foto pre-wedding yang dipilih secara purposif berdasarkan pada kecenderungan memiliki kode inkonvensional, menganalisa dengan semiotika fotografi terhadap foto pre-wedding yang
\end{abstract}

Authors are master degree student and lecturers from Faculty of Art and Design, Bandung Institute of Technology, email:wahyulukito37@gmail.com, intanrm@yahoo.com,ya_piliang@yahoo.com 
diunggah pada akun Instagram masing-masing vendor dalam rentang waktu tertentu, menjabarkan kode inkonvensional yang membentuk konsep inkonvensional yang memiliki potensi untuk membentuk mitos inkonvensional pada foto pre-wedding. Kode-kode inkonvensional terbentuk melalui pematahan kode konvensional. Pematahan kode melalui memodifikasi tanda visual, yang tidak umum pada foto pre-wedding. Proses tersebut juga membentuk konsep inkonvensional pada foto prewedding yang memiliki potensi untuk membentuk mitos inkonvensional dalam jangka waktu yang lama.

Kata kunci: Kode, Mitos, Pre-Wedding, Fotografi, Tanda

\section{INTRODUCTION}

The wedding party is one of the special ceremony were held on a large scale for the upper classes. Magnificent ceremony of a wedding party made many vendors interested to run wedding party business. Those vendors provide services and goods related to the wedding party, such as wedding organizer, bridal, party decoration, and also photo and video documentations. Among the vendors, photo and video vendors also offer pre-wedding photograph service. In Indonesia, bride and groom couples do pre-wedding photograph like a tradition before marriage. Through pre-wedding photograph they can express their personal identity, so they applied the theme on their pre-wedding photograph in accordance with their interest, hobby, and favorite.

'Pre-wedding' photography comes from English consisting of two words, namely 'pre' means before and 'wedding' means marriage. The term 'pre-wedding' photography has a severe error. According to one photography activist, Arbain Rambey (2009), photographers apart in Indonesia will be confused on the term because it is indeed an unusual photographic activity. Rambey also added prewedding photography emerged in Indonesia and to date only prevalent in Indonesian society. Prewed photograph (so-called) arose from here that "widen" 
photo shoot marriage to all facets. In the West, also does not recognize it, because they more familiar with the term engagement photograph (Rambey, 2009). Photography as a visual text is a record of reality, time slice. Reality in photography is different with the actual reality, because the camera tricks and tricks printing. However compared to the illustration, photography carry a payload of highly viscous objective (Iskandar, 2007).

In pre-wedding photograph there are visual signs, which break conventional codes, then create unconventional concepts, which have potentials to create unconventional myth on pre-wedding photograph. The objectives of this research are to identify visual signs, unconventional codes and concepts on prewedding photograph.

The research method is semiotic approach through matrix analysis. First, identify sign structures with the meanings; those are poses and objects in photograph. Next, explain the codes contained in those photos by Roland Barthes semiotic codes. This research only focuses on cultural, semantic, and symbolic codes. Then describe the myths contained in those photos.

\section{THEORETICAL BACKGROUND}

Paul Messaris found that photograph is a readable visual form (Iskandar, 2007). Photography is one of how to speak. It's a visual language form. As a language form, it is also product of mind, which in turns evolved into cultural product and thus creating a discourse of knowledge.

Signs in post-structural semiotics do not have to following the fixed structure (Susanto, 2013). They are heterogenic, plural with dynamic codes, not binding. In post-structural semiotics, social convention could be ignored. The one 
way of working of post-structural semiotics is intertextuality. Intertextuality is transposition a sign system to other sign system, followed by new articulation and expression. Intertextuality believe that used sign quotes from other sign systems, those also quotes from other sign systems, and so on. In post-structural semiotics also have double coding, that combine between two or more code systems in creating new eclectic codes. Intertextuality in code allows code become diverse and what there to create new meanings, where signified or meaning can be quotes from other sign system. Intertextuality also allow contradiction (Piliang, 2010)

In Roland Barthes semiotic, there are five types of codes commonly operated in sign (Vera, 2014) i.e. Hermeneutic, Proairetic, Cultural, Semantic, Symbolic. In Barthes's "The Photography Message" (Susanto, 2013) there are six procedures that can be regarded as 'writing' activity, because naturally through those procedures a photographer can decide some sign elements, relation etc. become main consideration when audiences read the visual language. Three of those six procedures directly influence the reality itself (modification of reality), those are trick effects, poses, and object selection.

Barthes explained that myth in this special definition is a development of connotation. The connotation had formed long in society (Vera, 2014). Although the myth is a social construction, myth as truths inherited and embedded in daily reasoning. Thus myth concept is almost equal to ideology concept, which worked on connotation level (Rachmawati and Nurrachmi, 2012). 


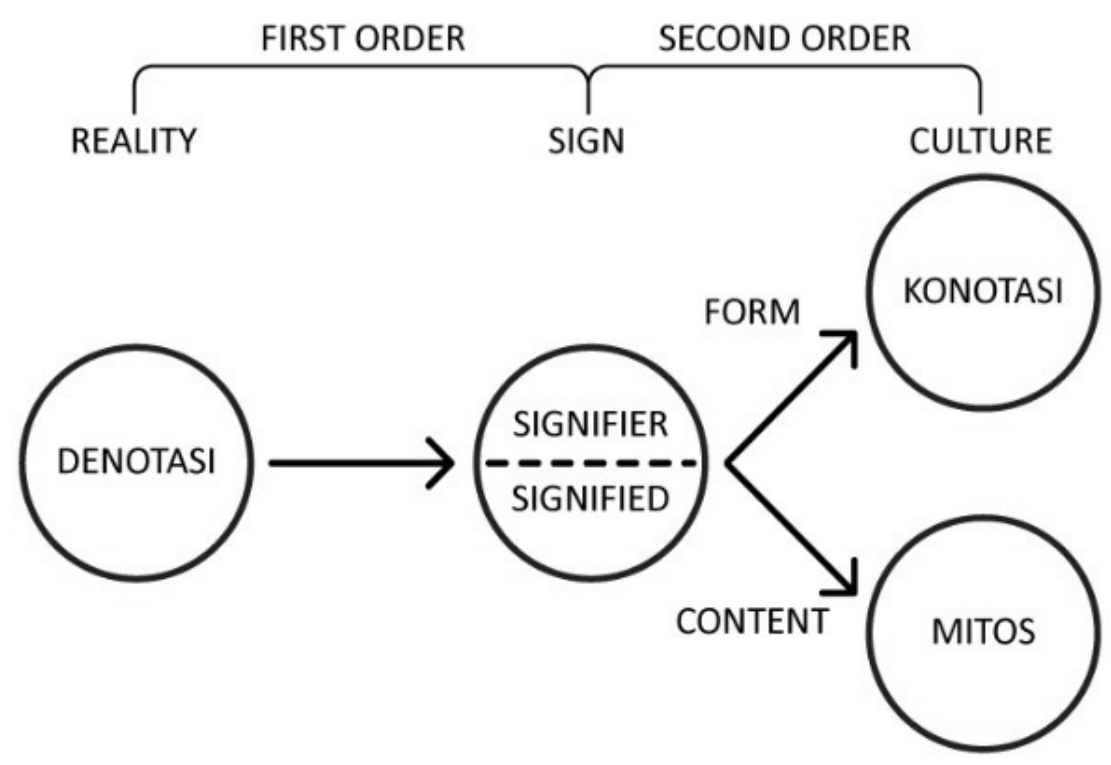

Figure 1 Roland Barthes chart myth Source: Sobur 2001:12

\section{THE RESEARCH METHOD}

Sampling collected by three aspects. First, pre-wedding photographs have visual signs consist of main characters and properties such as fashion style and background. Then, pre-wedding photographs created by pre-wedding photograph vendor in Bandung. And last, pre-wedding photographs suspected have unconventional codes and myths. Those selected pre-wedding photographs, created by pre-wedding photograph vendors in Bandung within 2010-2015; those are Polar Photography, Owlsome Project, and Rana Creative Visual. Samples collected from each vendor's Instagram account.

The research method is semiotic approach through matrix analysis. First, identify sign structures with the meanings; those are poses and objects in photograph. Next, explain the codes contained in those photos by Roland Barthes 
semiotic codes. This research only focuses on cultural, semantic, and symbolic codes. Then describe the myths contained in those photos.

Pre assumption: in pre-wedding photograph contained visual signs those break conventional codes, then create unconventional concepts which have potential to create unconventional myth on pre-wedding photograph.

\section{RESULT AND DISCUSSION}

The man sits on sofa, smiling to camera, right arm is on the armrest, left arm is straight on backrest, right leg cross on left leg. Those visual signs connoted relax, protect, and masculine. The woman sits on sofa, smiling to camera, both hand cross on thigh, left leg cross tight on right leg. Those visual signs connoted relax, graceful, and feminine. Although they sit on same sofa, there is a distance between them.

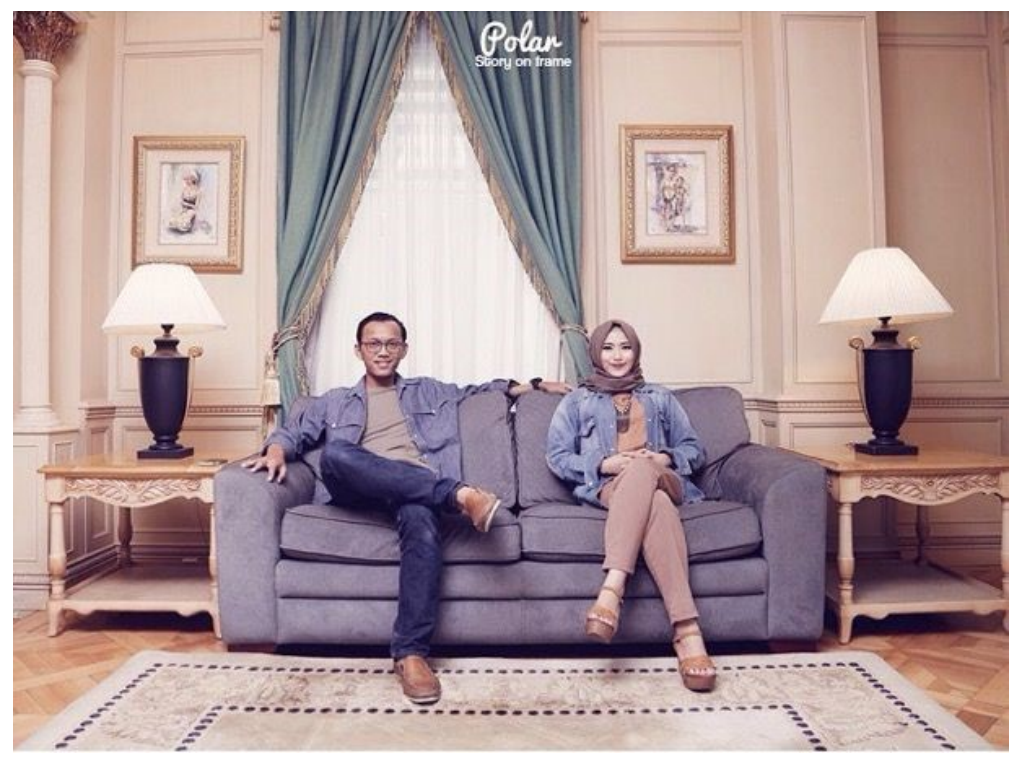

Figure 2 pre-wedding photographed by Polar Photography Source: Instagram (@polar_photograph), 2015 
Edward T. Hall in Purba (2006) intimate distance is about 0-18 inches and usually use for close related person only. The distance between them is a personal distance that about 18 inches. This is not like many pre-wedding photograph that shown romantic poses and intimacy. Both of them wear smart casual that image urban society. And the woman wear veil that imaged a Moslem. The background is classic Victorian style interior that imaged European luxury interior and highclass people (Mayangwangi, 2016).

On the Polar Photography's pre-wedding photograph above (Figure 2), there are visual signs, which create unconventional codes. The unconventional codes are cultural, symbolic and semantic codes. The unconventional cultural code created by clothes visual sign which main characters worn. In this photo, the main characters wear smart casual clothes that imaged urban society. The unconventional symbolic code created by clothes and interior room as the background. Both visual signs have contradiction in different style. The unconventional semantic code created by distance and main characters poses that not show intimacy. From this unconventional semantic code created a unconventional romantic concept, which has broke Edward T. Hall's theory about intimate distance. 


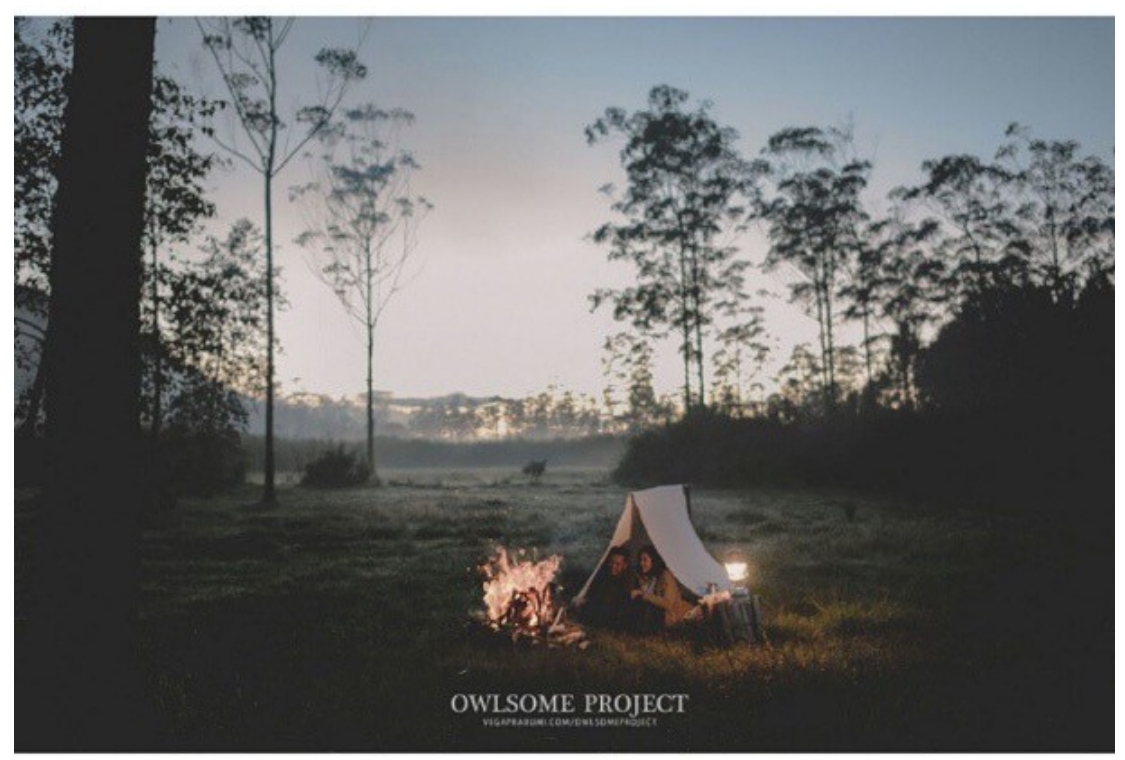

Figure 3 pre-wedding photographed by Owlsome Project Source: Instagram (@owlsomeproject), 2015

On the photo above (Figure 3), the man sits in camp, both of legs crisscross, right arm is holding a twig, laugh and staring at the bonfire. And the woman sits in camp too, both of arms hugging legs bent, laugh and staring at the bonfire. Their gestures are not showing romantic pose. Those visual signs connoted an adventurer and humorous. They wear adventurer clothes that image real adventurer. Camp and bonfire image adventurer camp. The jungle and sunset image wild, calmness, and timeless. Ami Ronnberg said that in West mythology, jungle imaged as quite, mysterious, bound, resting place, greatness, growth, timeless and life balance. In many mythology of some culture (Aborigine, West, and Egypt), sunset is the end of life (Hereafter portal opening) into eternal afterlife (Ronnberg, 2010).

The pre-wedding photograph above, have unconventional semantic codes that created by main characters poses, background, and theme. The main characters looks laughed, which has connoted humorous. The theme that applied 
on this photograph is adventure with adventurer clothes, which has connoted real adventurer on main characters. And the background is the jungle that has connoted calmness. Those pre-wedding photograph looks so different than mostly pre-wedding photographs those apply romantic theme and elegant. So the unconventional semantic code creates a unconventional concept for romantic myth in pre-wedding photography.

The man is standing behind the woman, with leg straight and open, left hand holding right arm in front stomach, starring far to right of him. Those visual signs connoted dashing, serious, and cool. The woman is standing in front of the man, body position is slightly tilted to right of her, left hand holding right hand that straighten, smile and starring to left of her. Those visual signs connoted shy and graceful. They wear Javanese traditional clothes that imaged Javanese traditional people. But, the man's Converse sneaker imaged urban casual teenager. The backgrounds are futuristic buildings those image metropolis.

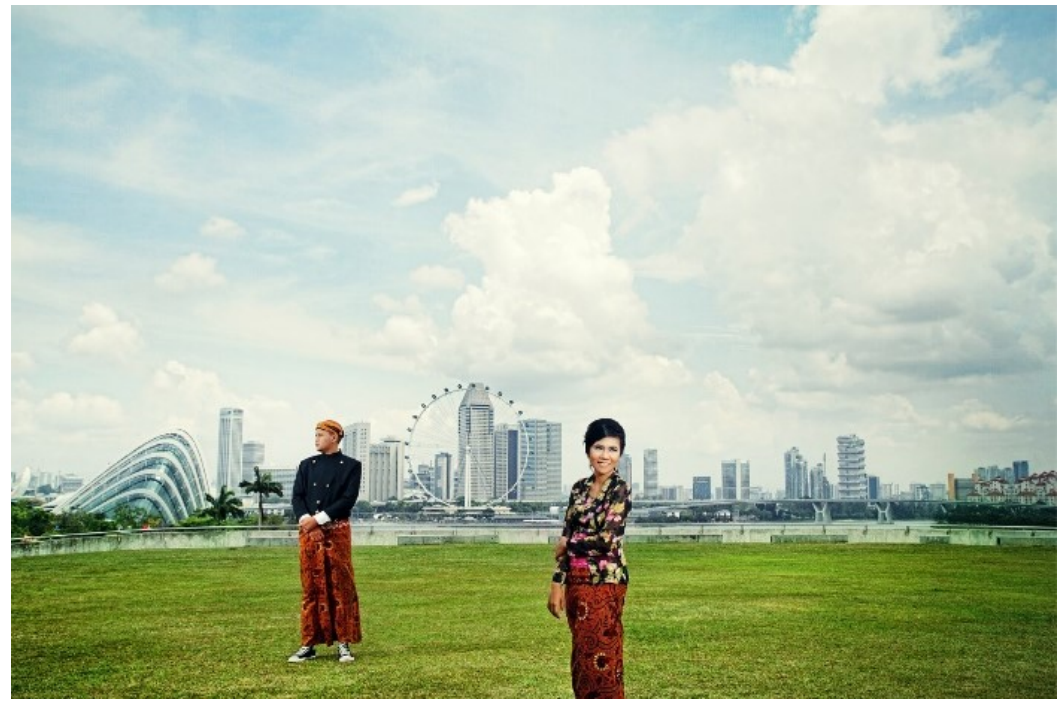

Figure 4 pre-wedding photographed by Rana Creative Visual Source: Instagram (@rana.creativevisual), 2015 
The pre-wedding photograph above has some unconventional codes; those are cultural, semantic and symbolic codes. Those unconventional codes created by poses, clothes and background visual signs. The unconventional cultural code created by main characters clothes visual sign. Both of them wear Javanese traditional clothes. The unconventional semantic codes created by main characters' poses those not image romantic gestures, and the distance is not image intimate. Besides, the background created unconventional semantic code that not show the calm place like on mostly pre-wedding photograph. The unconventional symbolic code created by clothes and background visual signs have contradiction in different style.

The clothes that worn by both main characters are Javanese traditional clothes, and the background are futuristic buildings. And also, the Javanese traditional clothes are looks contrast with the shoes that worn by the man. Usually, when wearing Javanese traditional clothes, the man should wear selop as footwear. But on this photograph, the man wears Converse sneaker as footwear. That shoes usually worn by urban society in casual moment. From those codes create unconventional concepts of myth in pre-wedding photograph. The unconventional semantic code that created by main characters poses visual sign, has broke intimacy distance theory. Then, the unconventional semantic code that created by background visual sign, create unconventional concepts of calmness myth in pre-wedding photograph. 
Table 1 analysis of visual sign matrix

\begin{tabular}{|c|c|c|c|c|c|c|c|c|c|c|c|}
\hline \multirow{2}{*}{ No } & \multirow{2}{*}{$\begin{array}{l}\text { Pre-wedding } \\
\text { Photograph }\end{array}$} & \multirow{2}{*}{ Visual Sign } & \multicolumn{3}{|c|}{ Roland Barthes Code } & \multicolumn{3}{|c|}{ Myth } & \multicolumn{3}{|c|}{ Anti-myth } \\
\hline & & & Cultural & Semantic & Symbolic & Romantic & Timeless & Calmness & Romantic & Timeless & Calmness \\
\hline \multirow{3}{*}{1} & \multirow{3}{*}{$\begin{array}{c}\text { Polar } \\
\text { Photography }\end{array}$} & Pose & & $\checkmark$ & & & & & $v$ & & \\
\hline & & Object & $v$ & & $\checkmark$ & & & & & & \\
\hline & & Background & & & $\sigma$ & & & & & & \\
\hline \multirow{3}{*}{2} & \multirow{3}{*}{$\begin{array}{l}\text { Owlsome } \\
\text { Project }\end{array}$} & Pose & & $\checkmark$ & & & & & $\checkmark$ & & \\
\hline & & Object & & $v$ & & & & & & & \\
\hline & & Background & & $\checkmark$ & & & $\checkmark$ & $v$ & & & \\
\hline \multirow{3}{*}{3} & \multirow{3}{*}{$\begin{array}{l}\text { Rana Creative } \\
\text { Visual }\end{array}$} & Pose & & $\checkmark$ & & & & & $\checkmark$ & & \\
\hline & & Object & $\checkmark$ & & $v$ & & & & & & \\
\hline & & Background & & $v$ & 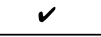 & & & & & & 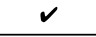 \\
\hline
\end{tabular}

Source: personal documentation

From Polar Photography's pre-wedding photograph, unconventional cultural code created by main character's clothes. The unconventional semantic codes created by poses and the distance of main character. The unconventional semantic codes create unconventional romantic concept, which have broken conventional romantic codes that identic with romantic pose and intimacy. The unconventional symbolic code created by the difference style of clothes and background.

In Owlsome Project's pre-wedding photograph, the unconventional semantic codes created by main character's poses that laugh connoted humorous. The clothes and properties in this photograph imaged adventurer life that looks different than many romantic pre-wedding photographs, which show romance and intimacy.

From Rana Creative Visual's pre-wedding photograph, the unconventional cultural codes created by the main character's clothes. Their poses create unconventional semantic code, which has broke conventional romantic myth. And also the unconventional semantic code created by the background applied, which create unconventional concept of calmness in pre-wedding photograph. The 
unconventional semantic codes created by the difference style of clothes and background, and also the contrast of clothes and shoes that worn by the man.

The interesting things to do for future research are study about the process anti-myth become unconventional myth in pre-wedding photography, and audience perceptions to respond pre-wedding photograph that contain unconventional concept or myth.

\section{CONCLUSION}

On pre-wedding photograph, there are visual signs that influenced meaning process. Those visual signs are poses and objects around main characters including the clothes worn. Main character's poses on pre-wedding photograph are not always touching and intimate to create warm and familiar impression. The matching shades of the objects around them reinforce the meaning (anchoring) in pre-wedding photograph. But through blending different shades objects make the photographs look unique and dynamic, and also create unconventional meaning on pre-wedding photograph.

From the third pre-wedding photographs, found unconventional codes. The unconventional codes created through breaking conventional codes process on them. The breaking process through modifies the visual signs, which not generally applied on pre-wedding photographs. And also the breaking process creates unconventional concepts on pre-wedding photograph, which have potential to create unconventional myths for long time. 


\section{REFERENCES}

Iskandar, A., 2007. Analisis Struktur Bahasa Fotografi Iklan Cetak Bank Negara Indonesia (BNI). Bandung: Tesis Magister Desain ITB.

Mayangwangi, N., 2016. Dominan, Klasik dan Berkelas Ala Victorian Style. [online] Available at <http://www.grya.co.id/stories/dominan-klasik-dan-berkelasala-victorian-style/> [Accessed 16 June 2016].

Piliang, Y. A., 2010. Hipersemiotika. Yogyakarta: Jalasutra.

Purba, A., 2006. Pengantar Ilmu Komunikasi. Medan: Pustaka Bangsa Press.

Rachmawati, A., and Nurrachmi, S., 2012. Cultural Studies: Analisis Kuasa Atas Kebudayaan. Surabaya: UPN Veteran.

Ronnberg, A., 2010. The Book of Symbols : Reflections on Archetypal Images. Köln: Taschen .

Rambey, A., 2009. Memahami Fotografi Prewedding. [online] Available at <http://kfk.kompas.com/blog/view/25729-Memahami-Fotografi-PreWedding> [Accessed 17 November 2013].

Susanto, E. B., 2013. Kajian Semiotika Karya foto Branding Senayan City (Studi Kasus : Karya Fotografi Nicoline Patricia Malina). Bandung: Tesis Magister Desain ITB.

Sobur, A., 2001. Analisis Teks Media: Suatu Pengantar untuk Analisis Wacana, Analisis Semiotik, dan Analisis Framing. Bandung: Remaja Rosdakarya.

Vera, N., 2014. Semiotika dalam Riset Komunikasi. Bogor: Ghalia Indonesia. 